\title{
ОСОБЛИВОСТІ ЗАБЕЗПЕЧЕННЯ ЯКОСТІ ПІДГОТОВКИ РЕГУЛЬОВАНИХ ПРОФЕСІЙ У РАМКАХ ДЕРЖАВНО-ПРИВАТНОГО ПАРТНЕРСТВА В ОСВІТІ ТА Е-МЕДИЦИНІ
}

\author{
Н. О. Сіненко ${ }^{1}$, Г. В. Загорій, С. І. Мохначов \\ Національна медична академія післядипломної освіти імені П. Л. Шупика \\ ${ }^{1}$ Національна академія державного управління при Президентові України
}

Поява е-медицини, процесів державно-приватного партнерства і пов’язане з цим стрімке збільшення мережі центрів неформального навчання, особливо у вирішенні завдань забезпечення регульованих професій, вимагає створення принципово нових підходів до конструювання системи освіти. Розглянуто питання забезпечення якості підготовки фахівців, що відносяться до класу «регульованих професій». Виділена думка, що в період швидкого розвитку предметних областей єдиним на даний час механізмом, що визначає потребу в додатковій освіті, іï обсяг та якості, є використання з цією метою онтологічних моделей знань предметної і пов’язаних з нею галузей.

Ключові слова: державно-приватне партнерство, професії, що регулюються, е-медицина, онтологічні моделі.

\section{ОСОБЕННОСТИ ОБЕСПЕЧЕНИЯ КАЧЕСТВА ПОДГОТОВКИ РЕГУЛИРУЕМЫХ ПРОФЕССИЙ В РАМКАХ ГОСУДАРСТВЕННО-ЧАСТНОГО ПАРТНЕРСТВА В ОБРАЗОВАНИИ И Е-МЕДИЦИНЕ}

\author{
Н. А. Синенко ${ }^{1}$, Г. В. Загорий, С. И. Мохначев \\ Национальная медицинская академия последипломного образования имени П. Л. Шупика \\ ${ }^{1}$ Национальная академия государственного управления при Президенте Украины
}

Появление е-медицины, процессов государственно-частного партнерства и связанное с этим стремительное увеличение сети центров неформального обучения, особенно в решении задач обеспечения регулируемых профессий, требует создания принципиально новых подходов к конструированию системы образования. Рассмотрены вопросы обеспечения качества подготовки специалистов, относящихся к классу «регулируемых профессий». Выделена мысль, что в период быстрого развития предметных областей единственным в настоящее время механизмом, определяющим потребность в дополнительном образовании, а также его объем и качество, является использование для этой цели онтологических моделей знаний предметной и сопряженных с ней областей.

Ключевые слова: государственно-частное партнерство, регулируемые профессии, е-медицина, онтологические модели.

(с) Н. О. Сінєнко, Г. В. Загорій, С. І. Мохначов 


\title{
FEATURES OF QUALITY OF REGULATED PROFESSIONS TRAINING WITHIN THE PUBLIC-PRIVATE PARTNERSHIP IN EDUCATION AND E-MEDICINE
}

\author{
N. O. Sinyenko ${ }^{1}$, G. V. Zagorii, S. I. Mokhnachov \\ Shupyk National Medical Academy of Postgraduate Education \\ ${ }^{1}$ National Academy for Public Administration under the President of Ukraine
}

The advent of e-medicine, the processes of state-private partnership and the associated rapid increase of nonformal education centers net, especially in solving problems to ensure the regulated professions, requires the creation of fundamentally new approaches to the design of the education system. The problems of the quality of training of specialists related to the class of «regulated professions» are examined. It is obtained the idea that in a period of rapid development of the subject areas the only mechanism that determines the need for additional education, as well as its scope and quality, is currently the use of ontological models and knowledge of the subject and associated areas.

Key words: public-private partnership, regulated professions, e-medicine, ontological models.

Вступ. Відповідно до визначення під регульованою (регламентованою) професією розуміють професійну діяльність, яка вимагає певних професійних кваліфікацій. Іншими словами, для роботи в регульованій професії треба відповідати умовам, зазначеним в законодавстві даної країни, і мати відповідні документи: сертифікати, ліцензії та інші документи, без яких не можна приступити до роботи в даному напрямку і на даній посаді [11]. До регульованих професій, перш за все, відносяться професії, надання послуг за якими пов'язано зі здоров'ям і безпекою громадян.

Особливі труднощі виникають у зв'язку з безперервно зростаючими обсягами інформації в предметних областях, появою нових погано формалізованих напрямків (наприклад, мобільної медицини тощо). Підготовку фахівців у конкретній країні все частіше проводять в неформальних центрах, що створюють шляхом державно-приватного партнерства. Підкреслимо, що нормативна база в Україні до цього певним чином підготовлена [3, 7].

Мета роботи: обгрунтування нових підходів у конструюванні системи освіти для вирішення проблем, пов'язаних із регульованими професіями.

Матеріали та методи дослідження. Дослідження носить теоретико-методичний характер. Використані методи: системно-аналітичний і контент-аналіз.

Результати та їх обговорення. В ст. 8 Директиви 2000/31/ЄС Європейського парламенту та Ради «Про деякі правові аспекти інформаційних послуг, що стосується регульованих професій» підкреслюється, що держави-члени ЄС повинні гарантувати, що використання комерційної ко- мунікації, яка становить інформаційну послугу, здійснювану представником регульованої професії, є предметом відповідності професійним правилам, зокрема, щодо незалежності, честі та гідності професії, професійної таємниці і ввічливості до клієнтів і інших представників професії. Без шкоди до автономності професійних органів і асоціацій, держави-члени ЄС і Комісія повинні заохочувати створення кодексів поведінки професійними асоціаціями та органами ЄС для того, щоб визначити тип інформації, яка може бути надана з метою комерційної комунікації, відповідно до національних правил. При цьому при розробці пропозицій щодо кроків ЄС, які можуть знадобитися для забезпечення належного функціонування внутрішнього ринку стосовно інформації про регульовані професії, важливо діяти в тісній взаємодії з відповідними професійними асоціаціями та органами [9].

Вважають, що в Україні інструментом регулювання повинні стати Національні рамки кваліфікації (НРК), які будуть інструментом сприяння розвитку таких напрямків, як визнання результатів навчання, навчання протягом усього життя і забезпечення якості результатів навчання в Україні, а також поліпшенню репутації українських кваліфікацій за кордоном.

Однак, незважаючи на те, що НРК були затверджені в 2011 році, та існував чотирирічний план впровадження (до 2015 року), в даному напрямку досягнуто дуже незначного прогресу: розроблені лише деякі нові професійні стандарти і кваліфікації, які базуються на результатах навчання; заснований Інститут професійних кваліфікацій 
та галузеві комітети; Міністерство соціальної політики розробило процедуру офіційного визнання неформального і спонтанного навчання; в нових законах «Про вищу освіту» та «Про професійнотехнічну освіту» містяться посилання на НРК; запропоновано Національне агентство із забезпечення якості вищої освіти (проте до теперішнього часу воно не приступило до роботи). Крім того, в Угоді про асоціацію, підписаною з ЄС, відзначено про створення НРК, які б відповідали Європейській рамці кваліфікацій.

Насправді, НРК поки що не застосовуються як система, вони не містять реєстру кваліфікацій. На практиці люди все ще посилаються на існуючі класифікатори професій, кваліфікаційні характеристики, освітні програми та державні освітні стандарти, які не базуються на результатах навчання, а також використовують існуючі класи, категорії і розряди (тарифні розряди) для опису різних рівнів кваліфікацій, а не НРК [13].

У той самий час інноваційний процес і промислове виробництво стрімко розвиваються. 3'являються нові спеціальності, зростає відповідальність за виконані дії, які не знаходять своє відображення ні в виробничих стандартах, ні тим більше в НРК. Перш за все, це стосується життєво важливих для країни напрямів - медицини і фармацевтики. Надзвичайно швидко зростають обсяги навчальної інформації. Існуючі в державі освітні структури насилу справляються зі зростаючими потребами суспільства. Стрімко розростається мережа центрів, що не відносяться до логіки і принципів формальної освіти. Останнім часом, поряд з формальним навчанням, при здійсненні навчання дорослих все частіше згадують такі види навчання, як «неформальне навчання» та «інформальне навчання», особливо в контексті підвищення кваліфікації або здійснення таких форм післядипломної освіти, як перепідготовка та стажування. Поява е-медицини, нанотехнологій, мобільної медицини, робототехніки остаточно загострило питання соціального партнерства.

У підсумку, проблеми освіти дорослих, створення методики оцінки компетенції фахівця, визначення якості навчання стали надзвичайно актуальними.

У спільному звіті Ради і Комісії за 2006 рік про результати, досягнуті в здійсненні робочої програми, акцентується, що основним завданням країн співдружності є формування таких громадських систем, які роблять можливим визнання та затвердження неформального та інформального навчання [13].
Поява стратегії інформальної освіти, яка є загальним терміном для освіти за межами стандартного освітнього середовища, пов'язана з індивідуальною пізнавальною діяльністю, що супроводжує повсякденне життя і не обов' язково носить цілеспрямований характер [13]. Таким чином, реалізується спонтанна освіта за рахунок власної активності індивіда в навколишньому культурно-освітньому середовищі, коли доросла людина перетворює освітній потенціал суспільства в дієвий фактор свого розвитку.

Підкреслимо, що неформальна освіта визначає будь-який вид організованої і систематичної діяльності, який може не збігатися з діяльністю навчальних закладів, що входять у формальні системи освіти. Найчастіше цей термін використовують паралельно з поняттями «безперервна освіта», «додаткова освіта», «самоосвіта». Беручи до уваги, що відсутність сертифікації часто є ознакою неформальної освіти, на жаль (і зазвичай), неформальна освіта розглядається в опозиції до формальної, що відбувається в рамках офіційних освітніх інститутів і супроводжується врученням офіційно визнаних документів про освіту [2, 5]. У той же час неформальна освіта поступово починає відігравати важливу роль в досягненні цілей програми «Освіта для всіх» та «Декларації тисячоліття» і відображає такі нові реалії, як диверсифікація освітніх потреб в мінливому суспільстві.

Таким чином, необхідно запропонувати об’єктивну методику, яка визначає потребу в додатковій освіті, її обсяг і якість.

Нами запропоновано використовувати 3 цією метою онтологічну модель знань предметної і пов’язаних з нею галузей, вперше запропонованих в [12].

Структура предметної онтології повинна відображати структуру предметної області. Зауважимо, що онтологію, яка включає поняття, що виходять за межі предметної області, що є найбільш загальними для двох і більше предметних областей, називають метаонтологією [4]. Важливою властивістю онтологічних i, особливо, метаонтологічних моделей є те, що одні й ті ж самі її об’єкти можуть розглядатися з різних точок зору за рахунок входження їх в різні концептуальні конструкції. Ця властивість онтологічних моделей дозволяє на їх основі встановлювати зв’язки між різними предметними областями, що є особливо актуальним для складних систем.

Очевидною складністю і перспективністю подібного роду досліджень є облік (і використання!) 
множини міжпредметних і міждисциплінарних зв'язків, а також різні цілі кінцевих користувачів системи. Підкреслимо, що онтологічні моделі знаходять останнім часом виключно широке розповсюдження в різних предметних областях [1, 6, 8]. Формально онтологія розглядається як триплет $\mathrm{O}=\{\mathrm{T}, \mathrm{R}, \mathrm{F}\}$, де $\mathrm{T}-$ множина концептів предметної області; R - множина відносин між концептами; F - функції інтерпретації, задані на сутності та/або відносинах онтології.

Відзначимо також, що паралельно повинна бути вирішена задача обміну достовірною інформацією, наборами даних між різними дослідницькими та освітніми центрами. 3 цього приводу інтерес становить стандарт CERIF (Common European Research Information Format) - спільний європейський формат для дослідницької інформації) [10].

\section{Література.}

1. Волохов В. Онтологическая модель предметной области информационной системы поддержки инновационных разработок институтов РАН / В. Волохов, А. Прохоров, Е. Амосова // Информационные ресурсы России. - 2011. - № 3. - С. 27-32.

2. Горшкова В. В. Взаимодействие формального, неформального и информального образования как современное направление развития человека [Электронный ресурс] / В. В. Горшкова // Концепт. - 2014. - Т. 26. - C. 176-180. - Режим доступа : http://e-koncept. ru/2014/64336.htm.

3. Деякі питання організації здійснення державно-приватного партнерства : постанова Кабінету Міністрів України від 11 квітня 2011 року № 384 [Електронний ресурс] / база даних «Законодавство України»; офіційний веб-портал Верховної Ради України. - Режим доступу : http://zakon3.rada.gov.ua/laws/show/384-2011-\%D0\%BF 4. Константинова Н. С. Онтологии как системы хранения знаний [Электронный ресурс] / Н. С. Константинова, О.А.Митрофанова // Всероссийский конкурсный отбор обзорно-аналитических статей по приоритетному направлению «Информационно-телекоммуникационные системы». - 2008. - 54 с. - Режим доступа : http://www. ict.edu.ru/ft/005706/68352e2-st08.pdf

5. Мельник С. В. Квалификации в сфере обучения на протяжении всей жизни: Как рассматривать профессиональные квалификации, в том числе приобретенные в результате неформального и спонтанного обучения, а также регулируемые профессии в Украине. Должны ли они входить в состав НРК? : аналитический обзор [Электронный ресурс] / С. В. Мельник ; Европейский фонд образования. - Киев, 2015. - 30 с. - Режим доступа : http://www.ipq.org.ua/upload/ files/files/03_Novyny/2015.12.10_LLL_qualifications_

\section{Висновки.}

1. Поява е-медицини, процесів державно-приватного партнерства та пов'язане з цим стрімке збільшення мережі центрів неформального навчання, особливо у вирішенні завдань забезпечення регульованих професій, вимагає створення принципово нових підходів до конструювання системи освіти.

2. Інформальна освіта набуває все більшого поширення.

3. Необхідно розробити об'єктивну методику, що визначатиме потребу в додатковій освіті, її обсяг і якість.

4. Для інтеграції освітніх центрів запропоновано використовувати онтологічні моделі предметних областей.

seminar/Analytic\%20Report_Qualifications\%20in\%20 LLL_Mr.\%20Melnik_RUS.pdf.

6. Норенков И. П. Интеллектуальные технологии на основе онтологий / И. П. Норенков // Информационные технологии. - 2010. - № 1. - С. 17-23.

7. Павлюк К. В. Сутність і роль державно-приватного партнерства в соціально-економічному розвитку держави / К. В. Павлюк, С. М. Павлюк // Наукові праці КНТУ. Економічні науки. - 2010. - № 17. - С. 10-19

8. Полетаева Е. В. Принципы построения онтологии предметной области машиностроения [Электронный ресурс] / Е. В. Полетаева // Программные продукты, системы и алгоритмы. - 2015. - № 1. - Режим доступа: http://swsys-web.ru/ontology-building-mechanicalengineering.html.

9. Про деякі правові аспекти інформаційних послуг, зокрема, електронної комерції, на внутрішньому ринку («Директива про електронну комерцію») Директива 2000/31/ЄС Європейського парламенту та Ради від 8 червня 2000 року [Електронний ресурс] / база даних «Законодавство України»; офіційний веб-портал Верховної Ради України. - Режим доступу : http://zakon4.rada. gov.ua/laws/show/994_224

10. CERIF 2008-1.2 Full Data Model (FDM). Introduction and Specification [Electronic resource] / B. Jörg, K. Jeffery, G. Van Groote [et al.] (eds) ; euroCRIS. - November 22, 2010. - 44 p. - Retrieved from : http://www.eurocris. org/Uploads/Web\%20pages/CERIF2008/Release_1.2/ CERIF2008_1.2_FDM.pdf.

11. Convention on the recognition of qualifications concerning higher education in the European region and explanatory report (Lisbon, 11.IV. 1997) / Council of Europe; UNESCO. - European Treaty Series. - 1997. - No. 165. $-300 \mathrm{p}$. 
12. Gruber T. R. The role of common ontology in achieving sharable, reusable knowledge bases / T. R. Gruber // Principles of knowledge representation and reasoning. proceedings of the second international conference / J. A. Allen, R. Fikes, E. Sandewell (eds.). - San Mateo, California : Morgan Kaufmann, 1991. - P. 601-602.

13. Modernising education and training: a vital contribution to prosperity and social cohesion in Europe - 2006 Joint Interim Report of the Council and the Commission on progress under the «Education \& Training 2010» work programme / Key messages to the Spring European Council. Communication from the Commission. - [EU CommissionCOM Document]. - Official Journal of the European Union 1.4.2006. - OJ 79/2. - C 79/1-C 79/19.

\section{References.}

1. Volokhov, V, Prokhorov, A., Amosova, E. (2011). Ontologicheskaya model' predmetnoi oblasti informatsionnoi sistemy podderzhki innovatsionnykh razrabotok institutov RAN [The ontological domain model of information system of support of innovations RAS institutes]. Informatsionnye resursy Rossii (Information resources of Russia), 3, 27-32 [In Russian].

2. Gorshkova, V. V. (2014). Vzaimodeistvie formal'nogo, neformal'nogo i informal'nogo obrazovaniya kak sovremennoe napravlenie razvitiya cheloveka [Interaction of formal, non-formal and informal education as the modern direction of human development]. Kontsept (Concept), 26, 176-180. Retrieved from: http://e-koncept.ru/2014/64336. htm [In Russian].

3. The Cabinet of Ministers of Ukraine. (April 11, 2011). Deyaki pitannya organizatsii zdiisnennya derzhavnoprivatnogo partnerstva [Some questions of the organization of the public-private partnership]. Decree No. 384. Retrieved from: http://zakon3.rada.gov.ua/laws/show/3842011-\%D0\%BF [In Ukrainian].

4. Konstantinova, N. S., Mitrofanova, O. A. (2008). Ontologii kak sistemy khraneniya znanii [Ontologies as a knowledge storage]. Vserossiiskii konkursnyi otbor obzorno-analiticheskikh statei po prioritetnomu napravleniyu «Informatsionno-telekommunikatsionnye sistemy» [Russian competitive selection overview and analytical articles on priority «Information and telecommunication systems»]. Retrieved from: http://www. ict.edu.ru/ft/005706/68352e2-st08.pdf [In Russian].

5. Mel'nik, S. V. (2015). Kvalifikatsii v sfere obucheniya na protyazhenii vsei zhizni: Kak rassmatrivat' professional'nye kvalifikatsii, $\mathrm{v}$ tom chisle priobretennye $\mathrm{v}$ rezul'tate neformal'nogo i spontannogo obucheniya, a takzhe reguliruemye professii v Ukraine. Dolzhny li oni vkhodit' $\mathrm{v}$ sostav NRK? [Excellence in learning throughout life: How to treat professional qualifications, including those acquired through informal and spontaneous learning, as well as the regulated professions in the Ukraine. Should they be part of the NQF?]: analytical review. Kyiv. Retrieved from: http://www.ipq.org.ua/upload/files/ files/03_Novyny/2015.12.10_LLL_qualifications_seminar/ Analytic\%20Report_Qualifications\%20in\%20LLL_ Mr.\%20Melnik_RUS.pdf [In Russian].

6. Norenkov, I. P. (2010). Intellektual'nye tekhnologii na osnove ontologii [Intelligent technologies based on ontologies]. Informatsionnye tekhnologii (Information technology), 1, 17-23 [In Russian].

7. Pavlyuk, K. V., Pavlyuk, S. M. (2010). Sutnist' i rol' derzhavno-privatnogo partnerstva v sotsial'noekonomichnomu rozvitku derzhavi [The nature and role of public-private partnerships in social and economic development of the state]. Naukovi pratsi KirNTU. Ekonomichni nauki [Scientific papers of KNTU. Economics], 17, 10-19 [In Ukrainian].

8. Poletaeva, E. V. (2015). Printsipy postroeniya ontologii predmetnoi oblasti mashinostroeniya [Principles of domain ontology of engineering]. Programmnye produkty, sistemy i algoritmy (Software products, systems, and algorithms), 1. Retrieved from: http://swsys-web.ru/ontology-buildingmechanical-engineering.html [In Russian].

9. Pro deyaki pravovi aspekti informatsiinikh poslug, zokrema, elektronnoi komertsii, na vnutrishn’omu rinku («Direktiva pro elektronnu komertsiyu») [On certain legal aspects of information services, in particular electronic commerce, in the internal market («Directive on electronic commerce»)]. (8 June 2000). Directive 2000/31/EC of the European Parliament and the Rada. Retrieved from: http:// zakon4.rada.gov.ua/laws/show/994_224 [In Ukrainian].

10. Jörg, B., Jeffery, K., van Groote, G., Asserson, A., Dvorak, J., Rasmussen, H. (Eds). (November 22th, 2010). CERIF 2008 - 1.2 Full Data Model (FDM). Introduction and Specification. Retrieved from: http://www.eurocris. org/Uploads/Web\%20pages/CERIF2008/Release_1.2/ CERIF2008_1.2_FDM.pdf.

11. Council of Europe, UNESCO. (11.IV. 1997). Convention on the recognition of qualifications concerning higher education in the European region and explanatory report. European Treaty Series, 165.

12. Gruber T. R. (1991). The role of common ontology in achieving sharable, reusable knowledge bases. In J. A. Allen, R. Fikes, E. Sandewell (eds.). Principles of knowledge representation and reasoning. Proceedings of the second international conference (pp. 601-602). San Mateo, California: Morgan Kaufmann.

13. Modernising education and training: a vital contribution to prosperity and social cohesion in Europe - 2006 Joint Interim Report of the Council and the Commission on progress under the «Education \& Training 2010» work programme. Key messages to the Spring European Council. Communication from the Commission. (2006/C 79/02). OJ 79/2. Official Journal of the European Union, 1.4.2006, C 79/1-C 79/19. 